Table 1 Effect of nucleoside-IgG2a conjugate on appearance of anti-nucleoside antibody forming cells

\begin{tabular}{cccc}
\hline Treatment $10 \mathrm{~d}$ & Direct (AGCT) PFC per spleen & Indirect (AGCT) PFC per spleen \\
on day 7 & $P$ & $P$ \\
ofore immunisation & $10,173 \pm 1,867$ & & $1,862 \pm 594$ \\
None & $1,888 \pm 480$ & $<0.001$ & $498 \pm 202$ \\
AGCT-IgG2a & $1,80.01$ \\
\hline
\end{tabular}

Seven BALB/c mice were treated with $0.2 \mathrm{mg}$ of AGCT-IgG2a, given i.v, and, together with seven untreated mice, were immunised i.p. with $0.2 \mathrm{mg}$ of AGCT-KLH in complete Freund's adjuvant $10 \mathrm{~d}$ later. Direct and indirect PFC were measured on day 7 , as described in the legend to Fig. 1. Values are means \pm s.e.

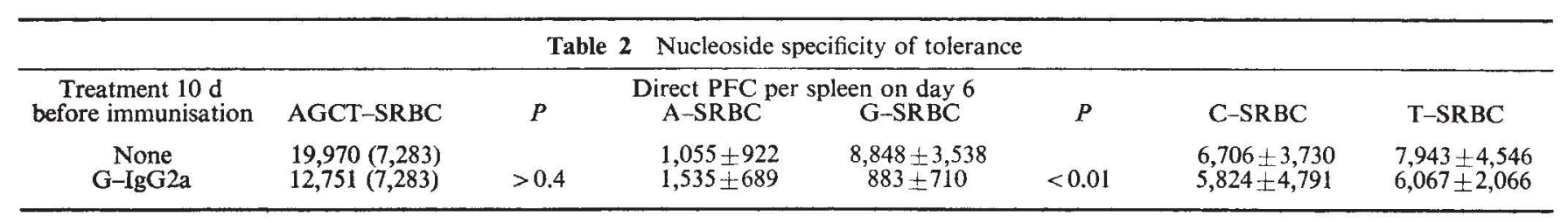

Seven BALB/c mice were treated with $0.2 \mathrm{mg}$ of G-IgG2a and, together with seven untreated mice, were immunised i.p. with 0.2 mg of AGCT-KLH in complete Freund's adjuvant 10 d later. Individual nucleoside-SRBC target cells were prepared as in the legend to Fig. 1 , but in each case $10 \mathrm{mg}$ of nucleoside were oxidised in $1.0 \mathrm{ml}$ of $0.1 \mathrm{M}$ sodium periodate. Direct PFC were measured $6 \mathrm{~d}$ after immunisation. Values are means \pm s.e.

immunised with all four nucleosides on the immunogenic carrier, there was some variation in the number of PFC specific for each nucleoside. This reflected at the cellular level of the immunodominance of guanosine and the low immunogenicity of adenosine that we have noted previously for serum antibody responses ${ }^{4}$. Finally, from a technical point of view, the modifications of the technique $c$ Erlanger and Beiser ${ }^{5}$ to link nucleosides to sheep cells should be noted. The ionic strength had to be maintained to prevent lysis. The use of $0.15 \mathrm{M}$ bicarbonate did this and provided a suitable $p \mathrm{H}$ for the Schiff base formation. The use of $t$-butylamine borane complex in place of sodium borohydride was important in preventing damage to the erythrocytes during reduction of the Schiff base, and the reduction time was brief.

The immune response to nucleic acid antigens is important from at least two points of view. First, since anti-nucleic acid antibodies are involved in autoimmune disease $^{\mathbf{z}}$, the suppression of this response can be of therapeutic importance; and second, strain differences in the ability of mice to respond to nucleic acid antigens have been observed ${ }^{9}$ and might offer the opportunity to study the genetic basis of both immunity and tolerance to defined determinants of naturally occurring antigens. The development of an assay that permits the detection of antibody forming cells to either all four nucleosides simultaneously or to individual nucleosides is useful for the study of these phenomena.

This work was supported by the US NSF, NIH and the Massachusetts Lupus foundation. We thank Ms L. Kilham for technical assistance.

\section{Department of Biochemistry and}

Pharmacology,

Tufts University School of Medicine,

Boston, Massachusetts 02111

Division of Immunology,

YVES BOREL

The Children's Hospital Medical Center,

Department of Pediatrics,

Harvard Medical School,

Boston, Massachusetts 02115

Received 2 February; accepted 10 March 1977.

1 Jerne, N. K., Nordin, A. A. \& Henry, C. L. in Cell Bound Antibodies 109-116 (Wistar Institute, Philadelphia, 1963)

2 Cunningham, A. J. Progr. Allergy 17, 5-50 (1973).

3 Stollar, B. D. \& Borel, Y. J. Immun. 115, $1095-1100$ (1975).

4 Stollar, B. D. \& Borel, Y. J. Immun. 117, 1308-1313 (1976)

Erlanger, B. F. \& Beiser, S. M. Proc. natn. Acad. Sci. U.S.A. 52, 68-74 (1967).

6 Golan, D. T. \& Borel, Y. J. exp. Med. 134, 1046-1061 (1971)

7 Borel, Y., Lewis, R. M. \& Stollar, B. D. Science 182, 76-78 (1973)

Koffier, D. J. exp. Med. 126, 607-623 (1967).

9 Fuchs, S., Mozes, E. \& Stollar, B. D. J. Immun. 114, 1287-1291 (1973).

\section{T-cell cytotoxicity in the absence of viral protein synthesis in target cells}

Cyтoтoxic $\mathrm{T}$ cells lyse only those virus infected target cells in vitro which express, in addition to the viral antigen(s), those $K$ or $D$ region products of the major histocompatibility complex (MHC) which were present during anti-viral sensitisation in vivo. This 'associative recogniton' by cytotoxic $T$ cells could reflect the interaction of two $T$-cell receptors with specificity for target $K$ or $D$ gene products and independently for the viral antigen, or one receptor

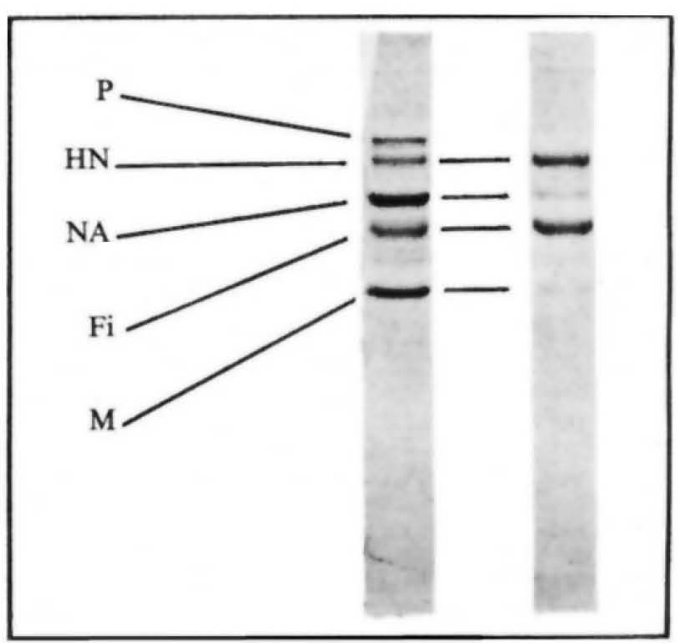

Fig. 1 Separation of Sendai virus envelope protein on SDSpolyacrylamide gels. Sendai virus $\left(8 \mathrm{mg} \mathrm{ml}^{-1}\right)$ in phosphatebuffered saline without $\mathrm{Mg}$ or $\mathrm{Ca}$ (PBS-A), $1.5 \times 10^{5}$ haemagglutinating units (HAU) per ml were treated with $0.25 \%$ NP 40 for $15 \mathrm{~min}$ at $20^{\circ} \mathrm{C}$ (ref. 6). The suspension was centrifuged at $120,000 \mathrm{~g}$ for $1 \mathrm{~h}$ at $4^{\circ} \mathrm{C}$ to remove partially disrupted virions and nucleocapsids. The supernatant was dialysed for $4 \mathrm{~d}$ at $4{ }^{\circ} \mathrm{C}$ against twice daily changes of PBS-A using spectrophor 2 tubing (Raven Scientific). The reassembled membrane particles were concentrated by centrifugation at $120,000 \mathrm{~g}$ for $1 \mathrm{~h}$ at $4{ }^{\circ} \mathrm{C}$ and the pellet was resuspended in PBS-A. Envelopes were active in assays for haemagglutination ${ }^{7}$, neuraminidase ${ }^{8}$ and haemolytic activities ${ }^{9}$. Envelopes were analysed by SDS-polyacrylamide electrophoresis by the method of Laemmli ${ }^{10}$ using $10 \%$ gels. $\mathrm{P}$, polymerase; HNA, haemagglutinin; NA, Neuraminidase; $F_{1}$, fusion factor; $M$, M-protein. 
with specificity for virally altered $K$ or $D$ region products (see ref. 1 and refs therein). There are various ways that the $\mathrm{MHC}$ antigens could be altered, including 'modification from within', where the virus modifies host protein synthesis by interfering with transcription ${ }^{2}$, translation or posttranslational glycosylation; or 'modification from without' where enzymic or chemical alteration of cell membrane proteins are induced by virus activity at the cell surface. In this report we show that inactivated Sendai virus or isolated Sendai virus envelopes can serve to modify a cell and make it a specific target for Sendai-immune T-cell killing, thus excluding the possibility of 'modification from within' in this system.

Sendai virus-primed BALB/c spleen cells, boosted in vitro with syngeneic infected blast cells, specifically killed Sendai virus-infected syngeneic target cells; primed spleen cells boosted with syngeneic non-infected cells did not (Table 1). Killer cells after secondary stimulation were $T$ cells as shown by treatment with anti-Ly-sera (U. K. and P. Beverley, unpublished). Three approaches were used to show that synthesis of viral protein is not required in the target cell in order for it to be killed by virally sensitised $T$ cells. First, cells incubated with ultraviolet-irradiated Sendai virus were lysed by sensitised $\mathrm{T}$ cells (data not shown). Second, cells exposed to purified Sendai virus, inactivated with $\beta$-propiolactone-which abolishes induction of protein synthesis by inactivated particles ${ }^{5}$ - also proved to be effective target cells (Table 1). Treatment with $\beta$-propiolactone reduced the number of plaque forming units by $10^{8}$. Since the ratio of particles to plaque forming units would be expected to be no better than $10: 1$ (J. Skehel, personal communication) and target-to-particle ratio was $1: 10^{6}$, it follows that, at most, one in a thousand cells were infected with a live virus. Sendai virus specific killer cells generated by secondary stimulation in vitro lyse only $H$-2-compatible infected target cells (U. K., unpublished) and the same restriction is seen using target cells incubated with inactivated Sendai virus (Table 2). Third, cells exposed to isolated envelopes from Sendai virus, which contained mainly the two surface glycoproteins with a very small amount of nucleocapsid and almost no detectable M-protein (Fig. 1), were susceptible to $\mathrm{T}$ cell-mediated lysis. To exclude nonspecific effects of the Sendai envelopes on target cells, influenza virus-specific cytotoxic $\mathrm{T}$ cells were tested on these target cells, and found to be ineffective (Table 3 ).

In several virus infections, target cell formation requires translation of early viral protein ${ }^{11-13}$, glycosylation ${ }^{14}$, and

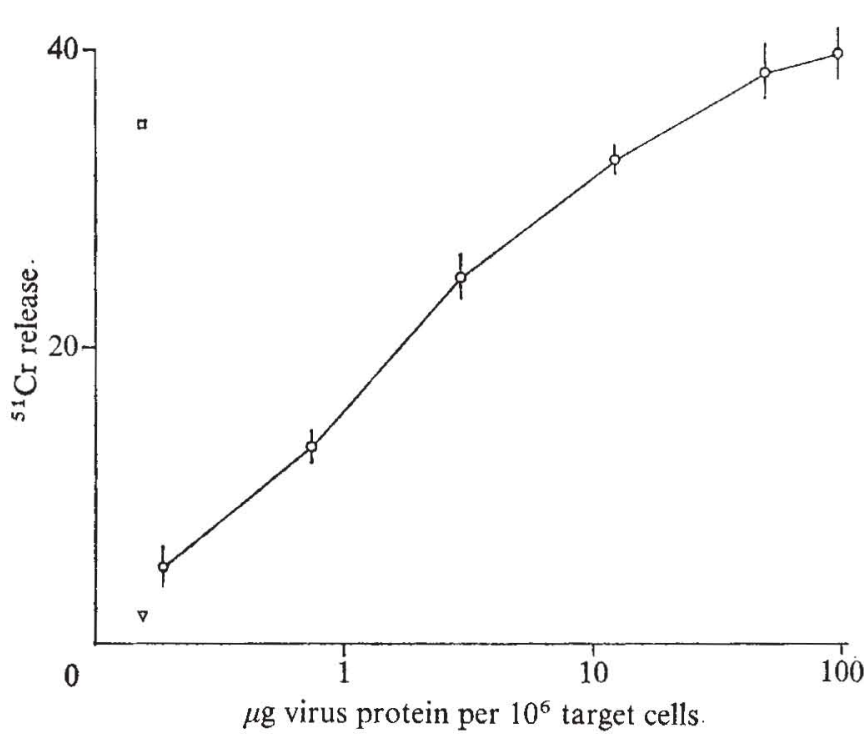

Fig. 2 T cell-mediated lysis of P-815 target cells exposed to dilutions of purified Sendai virus inactivated with $\beta$-propiolactone (B-PL). Sendai virus was grown in the allantoic cavity of 10 -d-old embryonated fowl eggs and purified by centrifugation through a sucrose gradient (20-55\% in PBS-A). The viruscontaining band was collected and concentrated by centrifugation at $120,000 \mathrm{~g}$ for $1 \mathrm{~h}$. Inactivation was achieved by incubating the purified virus ( $2 \mathrm{mg}$ per $\mathrm{ml}, 4 \times 10^{4} \mathrm{HAU}$ per ml, $1 \mu \mathrm{g} \approx 10^{11}$ virus particles) for $18 \mathrm{~h}$ at $4{ }^{\circ} \mathrm{C}$ with $\beta$-propiolactone (Sigma) at a concentration of $0.025 \%$. $\beta$-propiolactone was inactivated by incubation for $30 \mathrm{~min}$ at $37^{\circ} \mathrm{C}$. Inactivation was tested by egg infectivity titration ${ }^{15}$. $0-\mathrm{O}$, Lysis of P-815 cells exposed $2 \mathrm{~h}$ before test with dilutions of B-PL-Sendai virus $\left(100 \mu \mathrm{g}\right.$ virus per $10^{6}$ cells, about $10^{5}$ particles per cell). $\square$, P-815 targets infected overnight with 20 PFU per cell (1 PFU $\leqslant 10$ particles). $\nabla$, Non-infected P-815 control cells. Assay conditions identical to Table 1 , incubation time $3 \mathrm{~h}$, ratio of killer-target cells, $5: 1$.

expression of viral proteins on the cell surface. The ability of Sendai virus to by-pass these processes may be due to its unique capacity to mediate cell-cell fusion, which could allow the insertion of large amounts of virus glycoprotein into the target cell membrane. From the dose-response curve (Fig. 2) of target cell formation with dilutions of $\beta$-propiolactone inactivated Sendai virus, it can be seen that about $10^{6}$ particles per target cell were required to induce

Table 1 Lysis of syngeneic target cells incubated with infective and inactivated Sendai virus or vesicles containing viral envelope proteins

Responder cells

BALB/c, Sendai immune

$\mathrm{BALB} / \mathrm{c}$ con A treated blasts, Sendai infected

BALB/c,

Sendai immune

BALB/c,

Normal

$\mathrm{BALB} / \mathrm{c}$ con $\mathrm{A}$ treated blasts

BALB/c con A treated blasts, Sendai infected

$\underset{\text { day }}{\text { Culture }}$

$\underset{\mathbf{K} \cdot \mathrm{T}}{\text { Ratio }}$

5

$10: 1$
$5: 1$
$2.5: 1$

5

10:1

$5: 1$

5

$10: 1$

$5: 1$

Targets

P-815

1.1
0.3
1.7
2.8
3.5
0.1
0.6

P-815/Sendai

43.5
26.6
13.9

0.5
0.9
0.9
0.4

P-815/B-PL-S P-815/Sendai env.

$\begin{array}{rr}42.0 & 18.1 \\ 26.3 & 9.7 \\ 15.1 & 6.3 \\ 1.3 & 0.4 \\ 0.9 & 1.0 \\ 4.0 & 1.6 \\ 3.6 & 0.5\end{array}$

BALB/c mice were immunised to Sendai virus by i.p. injection of $0.2 \mathrm{ml}$ allantoic fluid containing $10^{7}$ plaque forming units (PFU) of virus ${ }^{3}$. Six weeks later spleens were collected and incubated in RPMI medium containing $10 \%$ foetal calf serum, glutamine and $5 \times 10^{-5} \mathrm{M}$ 2 -mercaptoethanol in $2 \mathrm{ml}$ well linbro plates in presence of stimulated cells. Stimulator cells were prepared by incubation of spleen cells in culture medium containing $2.5 \mu \mathrm{g} \mathrm{ml}-1$ concanavalin $\mathrm{A}$ (con A) for $48 \mathrm{~h}$ followed by overnight infection with 20 PFU per cell Sendai virus and 2,000 rad irradiation. $5 \times 10^{6}$ responder cells were incubated with $5 \times 10^{5}$ stimulator cells. Cytotoxic T cells were collected from cultures 4-7 d later ${ }^{4}$ and a ${ }^{51} \mathrm{Cr}$ release assay was performed with $5 \times 10^{3}$ syngeneic tumour target cells per well ${ }^{3}$. Target cells were $a$, ${ }^{51} \mathrm{Cr}$ labelled non-infected P-815 cells; $b$, P-815 cells infected overnight with 20 PFU per cell Sendai virus; $c$, P-815 cells pre-incubated for $2 \mathrm{~h}$ with $\beta$-propiolactone (B-PL) inactivated (see legend Fig. 2), purified Sendai virus in a protein concentration of $50 \mu \mathrm{g}$ per $10^{6}$ target cells; $d$, P-815 cells pre-incubated for $2 \mathrm{~h}$ with Sendai envelope (env.) proteins (see legend to Fig. 1) in a protein concentration of $50 \mu \mathrm{g}$ per $10^{8}$ target cells. Results are from triplicate assays; S.E.M. were always less than 3 . Spontaneous lysis, which did not exceed $15-20 \%$, is subtracted. 
Table 2 Lysis of target cells treated with $\beta$-propiolactone inactivated Sendai virus is $H-2$ restricted

\begin{tabular}{|c|c|c|c|c|}
\hline $\begin{array}{l}\text { Responder } \\
\text { cells }\end{array}$ & $\begin{array}{l}\text { Stimulator } \\
\text { cells }\end{array}$ & $\begin{array}{c}\text { P-815 S-B-PL } \\
\left(H-2^{\text {dd }}\right)\end{array}$ & $\begin{array}{c}\text { L-929 S-B-PL } \\
\left(H-2^{\mathrm{kk}}\right)\end{array}$ & $\begin{array}{c}\text { EL-4 S-B-PL } \\
\left(H-2^{\mathrm{bb}}\right)\end{array}$ \\
\hline $\begin{array}{l}\text { BALB/c normal } \\
\left(H-2^{\text {dd }}\right)\end{array}$ & BALB $/ \mathrm{c}$ con A treated blast, Sendai infected & 3.1 & 1.4 & 2.5 \\
\hline $\begin{array}{l}\text { BALB/c immune } \\
\left(H-2^{d \triangleleft}\right)\end{array}$ & BALB $/ \mathrm{c}$ con A treated blasts, Sendai infected & 46.1 & 1.5 & 11.9 \\
\hline $\begin{array}{l}\text { CBA immune } \\
\left(H-2^{\mathbf{k}}\right)\end{array}$ & CBA con A treated blasts, Sendai infected & 2.4 & 30.6 & 3.0 \\
\hline $\begin{array}{l}\text { C57BL6 immune } \\
\left(\mathrm{H}-2^{\mathrm{Db}}\right)\end{array}$ & C57 BL6 con A treated blast, Sendai infected & - & 3.8 & 32.5 \\
\hline
\end{tabular}

Conditions of immunisation and in vitro restimulation were as for Table 1. Cells were collected and tested on culture day 6. Target cells were incubated with B-PL-virus, in a protein concentration of $50 \mu \mathrm{g}$ per $10^{8}$ target cells. Results are from triplicate assays, ratio of killer-target cells is $20: 1$, incubation time $4 \mathrm{~h}$.

a comparable degree of killing as seen with infected target cells. Since the percentage of particles which actually fuse with the target cells is unknown, the number of fused particles per cell necessary for target cell formation cannot be estimated. Failure to use sufficiently high concentrations of virus during target cell incubation may explain previous negative findings (ref. 12, and U.K., unpublished).

$\beta$-propiolactone-Sendai virus-treated target cells were lysed to a similar extent as target cells incubated with live virus, but target cells which were produced with Sendai virus envelope vesicles were consistently lysed at a lower plateau level. Two explanations are possible. There could be two populations of Sendai virus specific cytotoxic T cells within'. If there are alterations of $H-2$ gene products these must occur from without, at the cell surface. Envelopes contain neuraminidase activity, but cleavage of neuraminic acid seems not to change the $\mathrm{H}-2$ surface antigen specificity ${ }^{16,17}$. We do not know if there are other residual enzyme activities such as proteases or glycosidases remaining in the envelopes. It is also possible that cross-linking of sialic acids by the viral haemagglutinin might change the surface distribution of $H-2$, and sometimes create effective target antigens.

Which then are the viral antigens on cell surfaces recognised by the $T$ cells? Recent studies on influenza virusspecific CTL have suggested that the M-protein which is

Table 3 Virus-specific lysis of target cells incubated with inactivated Sendai virus or Sendai virus envelopes

\begin{tabular}{|c|c|c|c|c|c|c|c|c|}
\hline $\begin{array}{l}\text { Responder } \\
\text { cells }\end{array}$ & $\begin{array}{l}\text { Stimulator } \\
\text { cells }\end{array}$ & $\begin{array}{l}\text { Culture } \\
\text { day }\end{array}$ & $\begin{array}{r}\text { Ratio } \\
\mathbf{K}: \mathbf{T}\end{array}$ & \multicolumn{5}{|c|}{ Targets } \\
\hline $\begin{array}{l}\text { BALB/c, } \\
\text { Sendai immune }\end{array}$ & P-815, Sendai infected & 5 & $\begin{array}{r}10: 1 \\
5: 1\end{array}$ & $\begin{array}{r}4.3 \\
-2.5\end{array}$ & $\begin{array}{l}2.3 \\
3.0\end{array}$ & $\begin{array}{l}39.6 \\
37.8\end{array}$ & $\begin{array}{l}28.1 \\
19.8\end{array}$ & $\begin{array}{l}19.3 \\
14.2\end{array}$ \\
\hline $\begin{array}{l}\text { BALB/c, } \\
\text { influenza immune }\end{array}$ & $\mathrm{P}-815$, influenza infected & 5 & $\begin{array}{r}10: 1 \\
5: 1\end{array}$ & $\begin{array}{r}-0.9 \\
0.2\end{array}$ & $\begin{array}{l}27.4 \\
13.9\end{array}$ & $\begin{array}{l}0.8 \\
0.3\end{array}$ & $\begin{array}{r}1.3 \\
-3.8\end{array}$ & $\begin{array}{l}1.8 \\
3.9\end{array}$ \\
\hline $\begin{array}{l}(\mathrm{C} 3 \mathrm{H} \times \mathrm{DBA} / 2) \mathrm{F}_{1}, \\
\text { Sendai immune }\end{array}$ & $\begin{array}{l}\text { BALB/c LPS blasts, } \\
\text { Sendai infected }\end{array}$ & 5 & $\begin{array}{r}10: 1 \\
5: 1\end{array}$ & $\begin{array}{r}-0.29 \\
1.02\end{array}$ & $\begin{array}{l}3.7 \\
1.4\end{array}$ & $\begin{array}{r}26.5 \\
8.6\end{array}$ & $\begin{array}{r}27.2 \\
8.5\end{array}$ & - \\
\hline
\end{tabular}

Responder cells $\left(B A L B / c,(C 3 H \times D B A / 2) F_{1}\right)$ were collected from mice injected i.p. 6 weeks previously with $10^{7}$ PFU Sendai virus or influenza virus. The influenza strain A/Jap/Bel/305/57 $\left(\mathrm{H}_{2} \mathrm{~N}_{1}\right)$ a recombinant of $\mathrm{A} / \mathrm{Jap} / 305 / 57\left(\mathrm{H}_{2} \mathrm{~N}_{2}\right)$ and $\mathrm{A} / \mathrm{Bel} / 42\left(\mathrm{H}_{0} \mathrm{~N}_{1}\right)(\mathrm{kindly}$ supplied by Dr J. Skehel) was used. Conditions of in vivo sensitisation and in vitro boosting of cells were similar to those used for secondary cytotoxic Tcell generation against Sendai virus. Stimulator cells were BALB/c lymphocyte blasts after $48 \mathrm{~h}$ incubation in $50 \mu \mathrm{g} \mathrm{ml} \mathrm{m}^{-1}$ lipopolysaccharide containing medium or P-815 tumour cells. Stimulator cells were infected overnight with 20 PFU per cell and irradiated with 2,000 rad (blasts) or 8,000 rad $(\mathrm{P}-815)$. Ratio of stimulator to responder cells and ${ }^{51} \mathrm{Cr}$ release assay conditions were identical to those described in the legend to Table 1.

with receptors for different viral antigens; however, antigens on envelope-treated target cells are at least partially shared with those of infected target cells since the latter compete in cold cell inhibition tests with the lysis of target cells exposed to Sendai virus envelopes (data not shown). The second possibility is that the envelope vesicles are less active in fusing with the target cell membrane; this is the more likely explanation since the $\beta$-propiolactone inactivated virus was active in cell -cell fusion, while the envelopes were not.

These results rule out, at least for Sendai virus infection, formation of an 'altered self' by a 'modification from not glycosylated and not expressed on cell membranes may contribute to target specificity ${ }^{18}$. This is very unlikely for Sendai virus since the envelope preparations contain only two glycoproteins, one with neuraminidase and haemagglutinin activity and the other with fusion activity.

These results show for the first time that target cells for virus-specific T-cell lysis can be prepared with vesicles containing essentially only viral surface glycoproteins and that viral protein synthesis is not required for target cell formation.

We thank Drs Martin Raff and Peter Beverley for helpful discussion and Rowan Coyle and John Sever for technical 
assistance. U.K. was supported by Deutsche Forschungsgemeinschaft and M.W. by the American Heart Association.

ICRF Tumour Immunology Unit,

\section{U. Koszinowsk I}

University College London,

Gower Street, London WCl, UK

\section{J. Gething}

M. WATERFIELD

Imperial Cancer Research Fund Laboratories,

Lincoln's Inn Fields,

London $W C 2$, UK

Received 1 February; accepted 14 March 1977

1 Munro, A. \& Bright, S. Nature 264, 145-152 (1976).

2 Garrido, F., Schirrmacher, V. \& Festenstein, H. Nature 259, 228-229 (1976).

Ertl, H. \& Koszinowski, U. Immunobiology 152, 128-140 (1976).

Neff, J. \& Enders, J. F. Proc. Soc. exp. Biol. Med. 127, 260-267 (1968).

Hosaka, Y. \& Shimizu, Y. K. Virology 49, 627-639 (1972)

Salk, J. J. Immun. 49, 87-98 (1944)

Aminoff, D. Biochem. J. 81, 384-392 (1961)

Shimizu, Y. K. J. Virol. 9,842-852 (1972).

Laemmli, U. K. Nature $227,680-685(1970)$

1 Ueda, Y. \& Tagaya, I. J. exp. Med. 138, 1033-1043 (1973)

Ada, G. I., Jackson, D. C., Blanden, R. V., Tha Hla, R. \& Bowern N. A. Scand. J. Immun. 5, 23-30(1976).

Koszinowski U. \& Ertl, H. Eur. J. Immun. 6, 679-683 (1976).

4 Jackson, D. C., Ada, G. I., Hapel, A. J. \& Dunlop, M. B. C. Scand. J. Immun. (in the press).

15 Scheid, A. \& Choppin, P. W. Virology 62, 125-133 (1974)

16 Sandford, B. H. \& Codington, J. F. Tissue Antigens 1, 153-161 (1971)

17 Ray, B. K. \& Simmons, R. L. Proc. Soc. exp. Biol. Med. 142, $846-852$ (1973) Effros, R. B., Doherty, P. C., Gerhard, W. \& Bennink, J. J. exp. Med. (in the press).

\section{Cellular inactivation by ultrasound}

THE lethal effect of ultrasound (US) on mammalian cells has received relatively little attention. Understandably, potential genetic aspects of US have been of prime concern to physicians who use US as a diagnostic tool; at the average power densities involved $\left(\ll 1 \mathrm{~W} \mathrm{~cm}^{-2}\right)$ little, if any cell killing is to be expected. There have been sporadic attempts to use higher intensities $\left(\sim 1 \mathrm{~W} \mathrm{~cm}^{-2}\right)$ as a treatment modality in cancer therapy ${ }^{1,2}$, but those experiments seem to have been based on inadequate cellular studies. The effects of US usually were evaluated in terms of morphological criteria rather than on quantitative determination of the loss of viability as measured by colony formation. There are few reports of the effects of US on survival of mammalian cells ${ }^{3,4}$, and none specifically examine hyperthermic interaction. With the increased interest in hyperthermia for tumour therapy, attention has been directed towards the use of ultrasound to achieve tumour heating. In preliminary experiments in which US was used to heat the EMT6 sarcoma and KHJJ carcinoma in mice, we found a high percentage of tumour cures with short $(\sim 30 \mathrm{~min})$ treatments at temperatures $\left(43-44{ }^{\circ} \mathrm{C}\right)$ where in vitro results of hyperthermia-induced cell killing ${ }^{5-7}$ would not have led to a prediction of any cures. We therefore initiated an investigation of the effects of US on survival of Chinese hamster cells to see if direct cell killing by US could explain our in vivo results, or, as in the case of radiofrequency (RF) electromagnetic heating, we would be forced to invoke host response ${ }^{8}$. In particular, we examined the thermal and non-thermal components of cellular inactivation by US. We report here that there is a definite non-thermal cytotoxic effect of US. Its relative contribution to cell killing is a highly nonlinear function of the temperature of the cellular milieu. The survival curves show clearly that, beyond an initial threshold, small changes in temperature and/or US intensity can give rise to impressive changes in survival values. The threshold nature of the data strongly suggests that by means of overlapping heams, ultrasound energy could be delivered to tumour tissue to achieve massive cell killings while sparing normal tissue outside the tumour volume to a degree far exceeding that of conventional techniques.

Chinese hamster cells (HA-1) of ovarian origin were maintained in Eagle's MEM supplemented with $15 \%$ foetal calf serum, penicillin, and streptomycin. The cultures were kept in a humidified incubator with a mixture of $95 \%$ air and $5 \% \mathrm{CO}_{2}$, and were routinely checked for mycoplasma. To maximise the transmission of the acoustic energy and hence minimise heat induced by absorption of US, cells were grown as monolayers in specially designed stainless steel dishes with Mylar bottoms (130 $\mu \mathrm{m}$ thick). Approximately $8 \times 10^{4}$ cells were seeded within a confined area $(1.6 \mathrm{~cm}$ in diameter) on the thin Mylar film; experiments were always performed on the third day after plating when the cell density reached approximately $5 \times 10^{5}$ cells $\mathrm{cm}^{-2}$ and the cells were still in exponential growth. Plating efficiencies of cells trypsinised from the Mylar film were $70-90 \%$. Some experiments were performed with cells in suspension; as far as possible, the geometry was identical to that used for attached cells. The cloning technique of Puck and Marcus was used to determine the fraction of viable cells. The US irradiating system consisted of a laboratory-developed signal generator and power amplifier driving a piezo-electric transducer (Mettler Electronics). The transducer was mounted on the frame

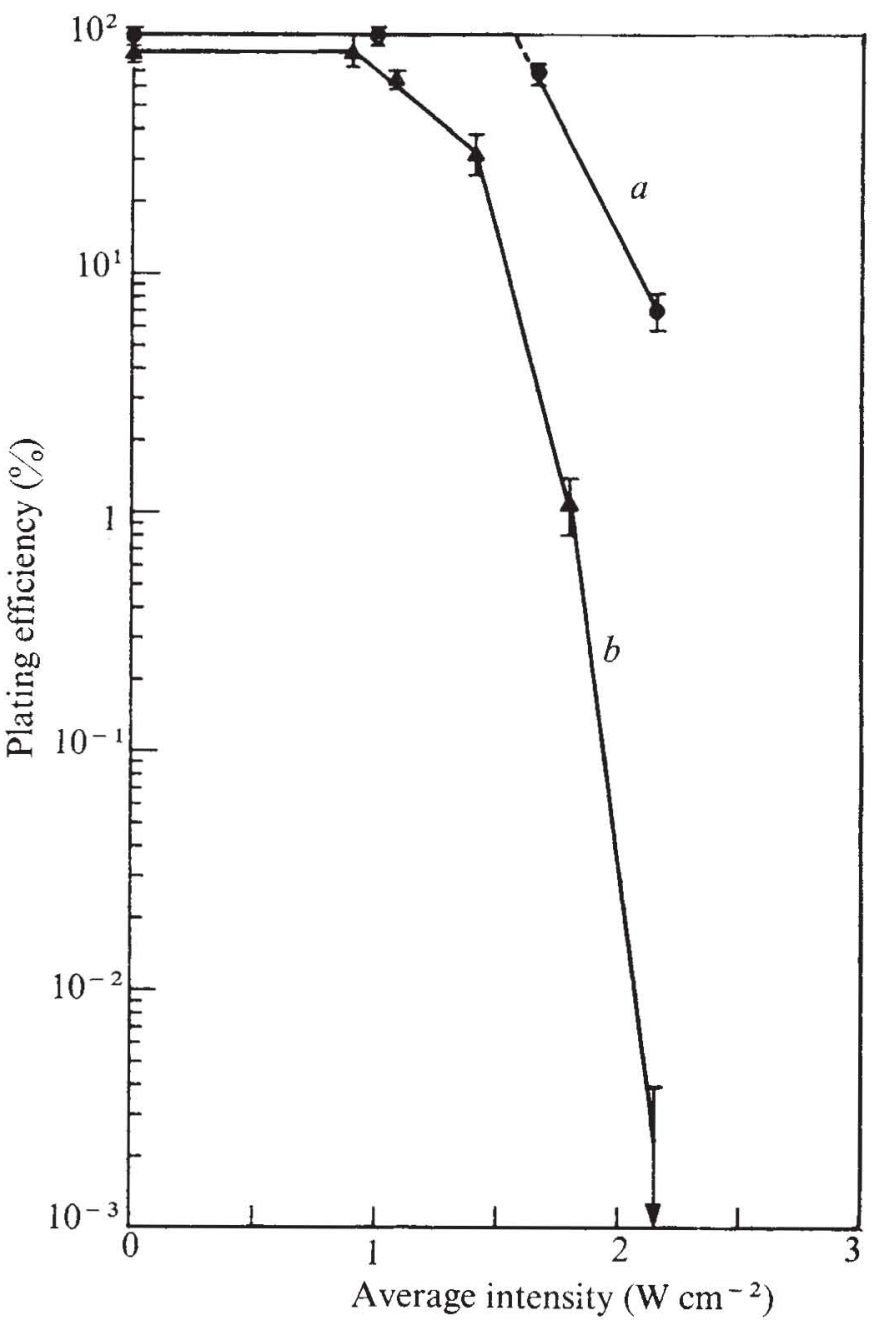

Fig. 1 Plating efficiencies (normalised to untreated controls) against US intensity. Cells were irradiated for $30 \mathrm{~min}$ at $a, 37^{\circ} \mathrm{C}$; $b, 43{ }^{\circ} \mathrm{C}$. Error bars in this and the succeeding figures show s.e.m. Plating efficiency is defined as (no. colonies per dish/no. cells plated per dish) $\times 100$. Cells plated per dish represents countable cells obtained by enzymic removal from Mylar after treatment. 